\title{
The Role of Political Parties in Building Loyalty Women Cadres through Political Education
}

\author{
Hariyanti Hariyanti*, Cecep Darmawan, Iim Siti Masyitoh \\ Civic Education Department \\ Universitas Pendidikan Indonesia \\ Bandung, Indonesia \\ *hari_yanti@student.upi.edu
}

\begin{abstract}
This study aims to describe how the role of political parties in building the loyalty of women cadres through political education. Efforts to build the political literacy of women cadres through political education need to be balanced with loyalty to the party in order to strengthen the party system in Indonesia. The development of political parties is determined by the loyalty of the cadres as a factor driving the functions of political parties. This research uses qualitative approach with descriptive method. The research findings show that the party established the loyalty of women cadres through the alignment of political education materials with the vision, mission and platform of the party struggle. Political education aims to shape political personality, political awareness and political participation. Political education plays a role to build cadre loyalty in order to minimize the phenomenon of "Kutu-loncat" politician because politics is solely seen from the point of view of power.
\end{abstract}

Keywords—political parties; loyalty of women Cadres; political education

\section{INTRODUCTION}

Political parties are one of the pillars of the political system of democracy. As a constitutional democracy, Indonesia empowers political parties to support the ongoing democratic process. The Government regulates the guidance and empowerment of the party through Law No.2 Year 2011 on the amendment of Law No.2 Year 2008 on political parties. A political party is a group of organizations whose members have the same orientation, values and ideals. The aim of this group is to acquire political power and seize the political position (usually) in a constitutional way through elections-to carry out its program, placing its candidates for public office [1]. Thus, a political party is a legal group in seizing and maintaining power, aiming to implement the policy according to the ideology, platform, vision and mission of the political party. Ideology is the first basis the party must have to define its line of struggle and place its position in the determination of attitudes, points of view and policies. Political parties can perform their functions and achieve goals with programmatic, intellectual, cadre-based skills and loyalty. Political parties are the party burdened by the law No.2 of 2008 on political parties to conduct political education, both to party cadres and to the wider community and even become a priority function in the change of political party law [2].
According to Article 11 paragraph (1) of Law No.2 of 2008 on political parties, it is stated that Political Parties function as a means: (a) political education for members and the wider community to become Indonesian citizens aware of their rights and obligations in life society, nation and state, (b) creating a conducive climate for the unity and unity of the Indonesian people for the welfare of society; (c) absorbing, gathering and channeling the political aspirations of the people in formulating and defining state policies; (d) the political participation of Indonesian citizens; and (e) political recruitment in the process of filling political office through democratic mechanisms with due regard to gender equality and justice. Anthony Downs declared the party to be a team that seeks control of the government apparatus by obtaining public office through institutional elections [3]

Political parties play an important role in encouraging women's political participation in internal party and legislative bodies because women have different experiences and interests with men. In addition, political parties must also provide treatments to increase women's competence to participate in political competition and minimize obstacles in the implementation of political education that leads to low women's political participation. However, what happens today, party cadres tend to be pragmatic by prioritizing personal political interests so often not encountered a politician jump fence or also known as a "kutu loncat" politician is a behavior of politicians who move from one party to another political party.

The phenomenon of "kutu loncat" politicians is not new in politics. Such behavior is accepted, understood, and considered as something reasonable. There are various reasons for the "kutu loncat" politicians to move parties such as (1) ideological issues and platforms of party struggle that are considered inconsistent with the political realities that occur; (2) feel his position is threatened by the presence of new politicians in the party; (3) the small opportunity to maintain political office either in party or in government with party stretcher; (4) the lack of opportunities to gain a brilliant political career and be greeted by the seduction of other parties with the promise of a better political position than in the old party. Women cadres are quite interesting political actors to be examined for the following reasons (1) the state encourages, protects and accommodates women's political participation through affirmative action policy; (2) women are the target of 
the largest potential voters and recruiting women as cadres is a party's strategic move to accommodate women's political representation; (3) women who decide to join a political party tend to be influenced by personal relations such as brotherhood and friendship so that it is interesting to examine the role of the party and empower and build the loyalty of women cadres for party work and serve in government.

The issue of loyalty of political party cadres is actually a matter of lack of knowledge and awareness of ideology so stuck with pragmatic-transactional political interests. This study aims to describe the role of political education to build the loyalty of female cadres to political parties in the regional leadership councils of the party of West Sumatera. As a new party, Nasdem party comes with ideology and tagline that is quite interesting and prestigious. The idea of Indonesian restoration of the change movement is offered to every citizen to join the party of nasdem and strive together to realize the party's goals. Party ideologies and platforms are the guidance for the cadres, especially the female cadres who tend to often "waver" in the political stream. This article seeks to describe how the role of political education in building the loyalty of women cadres through political education and what materials are given by the party to the cadres to build the political literacy of the cadres.

\section{THEORETICAL}

The cadre of political party is a group of citizens who are trained in a cadre education in a political party organization in order to be a force for political parties to achieve the goals of the political parties [4]. The purpose of political education for cadres can be from the first aspect of cognitive to build the knowledge of citizens (civil society) about the basic concepts of politics and government. Second, affective aspect, to form the character of citizen (civil society) that side with democratization and identity as the holder of sovereignty Third, psychomotor aspects to build intellectual and moral skills in realizing a democratic Indonesia. A person's understanding of politics will be largely determined by the political "learning" process he receives in his life that will bear his own perceptions. One's perception is determined by the relationship between things that are believed and what is expected. Perception is strongly influenced by past experience factors, socio-cultural background, motivation and mood. Perception greatly determine one's attitude. Through perceptions that serve as filters, one builds trust and motivation for the political stimulus in the real world [5].

Political education is an effort devoted by formal and non-formal educational institutions that seek to shape and foster a political personality that is in line with the political culture of those who operate in institutions the institution-in every citizen, shapes and fosters political awareness at all levels, which citizens become aware of and able to gain their own consciousness, shaping and fostering the ability of political participation that he or she is capable of and actively participating in politics in solving the problem- the general problems of society with all possible forms of participation and which lead to change for the better. Political education by the party plays a strategic role in shaping citizens, especially party cadres, to have political personality, political awareness and able to participate actively and responsively because the cadres are part of practical political actors involved in the circulation of public power. First against female cadres, political education by the party can be a stepping stone to increase the political participation of female cadres both at the internal level of the party and in government [6].

Women cadres occupy strategic positions because apart from being politicians, she is also the wife and mother at home and members of the community and other associations so that good knowledge and skills can be provisioned in providing political education for those environments and are sensitive to their aspirations and needs. The form of political education by the party will be influenced by the party's vision, mission, and platform so that it can produce different political education models that include political strategy, materials and methods of education. The process of political education in the party is correlated with the political participation of women cadres.

Sidney Verba argues that the most important contribution of women in politics is that they are more interested in doing something useful for society than to broaden the scope of power [7-9]. There are at least three profiles of women politicians based on their recruitment and social mobility process [10]. First, women who are involved in politics because they have independent intellectual and organizational abilities. This women politician model can be called achieved woman politician. Second, women who gain political office not because they fully have political skills or because of their business in a way, but they get a political position because of its relationship with certain men who have important political position. This kind of female politician is referred to as ascribed woman politician. Third, women politicians who reach political positions because they have collusion with bureaucracy. Politicians like this have patrons.

Men and women cadres have their own interests in dealing with public affairs. Women politicians have different concerns with male politicians, they tend to pay attention to the social needs of public services such as public health rather than issues surrounding the defense of power. A number of research findings in some countries, such as the United States, suggest that the high number of women's political representation in parliament is related to the lack of infant mortality in the United States in the period 1990-2012 and also in the Indian Bihar area attributed to women politicians' concern in promoting the progress of public health $[11,12]$. Then, the life satisfaction / quality of life is high in countries with high women's political representation because one of the indicators used is public health service given priority [13]. However, it is also acknowledged that women's leadership does not necessarily influence political policies such as the results of research in several cities in the United States where the position of female mayors does not affect the size of local government, regional expenditure and crime rates. Nevertheless, women who win in political contestation are women who have superior political skills compared to men [14]. So, it is not based on charity but political skill of women politicians. 


\section{METHOD}

This research uses qualitative approach with descriptive method. The research was conducted at the Regional Executive Board (DPW) of the NasDem Party of West Sumatra Province. The research instrument is the researcher itself. As the main instrument, researchers can interact directly with the research subject in depth so that researchers can analyze and interpret the answers given subjects [15]. That "human instrument serves as setting the focus of research, selecting informants as data sources, collecting data, assessing data quality, analyzing data, interpreting data, and drawing conclusions on its findings. Determination of informant research through technique of nonprobability sampling with purposive sampling technique. Data collection through interview techniques and documentation. Data analysis includes data reduction, data presentation and conclusion drawing and verification. The technique of testing the validity of the data using source triangulation.

\section{RESULT AND DISCUSSION}

The existence of women in party politics gives its own color because it has educational background, socio-cultural, experience and angle of field with male politician so that political activity becomes more interesting and constructive because it is rich in difference of paradigm in acting political event happened. The role of political parties generally affects the concepts of thinking and political activity of women cadres. Therefore, political parties play a strategic role in shaping the political literacy of women cadres through the function of political education, thus not only forming the personality, awareness and cadre political participation but also must be balanced with the loyalty of female cadres to the party.

Talking about women and politics, cannot be separated from the image and social construction of women in community relations. Perceptions of women in patriarchal society tend to be negative. The images that have been confirmed in the minds of society are stereotypical concepts of women in various sectors, including in the political and government sectors. Mostly stereotyped images of women are eventually "drawn" into the public world-including in the political world-that women are "unfit" to lead because women are irrational and rely more on their emotions. This publicprivate dichotomy prevents the participation and political representation of female cadres [16]. When engaged in practical politics, women must be themselves, relying on their knowledge, experience and political skills to give color to the political process. Sidney Verba argues that the most important contribution of women in politics is that they are more interested in doing something useful for society than to broaden the scope of power [7-9].

Party nasdem is one of the political parties in Indonesia. Party nasdem formed with the ideals of restoring Indonesia. The idea of Restoration Indonesia Movement of Change which became the foundation of the cadre's struggle in every political education program of the party so as to form a cadre who understand the spirit and line of the party struggle. Restoration Indonesia aims to realize the independence of Indonesia as a whole which means the people of Indonesia are more advanced and prosperous, the nation of Indonesia increasingly united and NKRI increasingly strong, dignified, and respected international world.

Based on the constitution of the Nasdem Party it is stated that the vision of the Nasdem party is "an independent Indonesia as a nation state, sovereignly economic and dignified in culture". In addition, the mission of the party nasdem namely (1) Building a democratic politics fair means creating a democratic re-order that opens people's political participation by opening access to society as a whole. Develop a model of civic education to strengthen the nation's character, and make changes to the efficiency of the electoral system. Establish bureaucratic reforms to create a community service system. To reform the law by making the constitution of the 1945 Constitution as the national political contract; (2) Creating economic democracy through economic democratic order creates participation and public access in the economic life of the country, including a fair and equitable economic distribution that will culminate in the welfare of all the people of Indonesia. In realizing these ideals it is necessary to encourage job creation, national social security systems, strengthening national industry and promoting economic independence at the local level; (3) Making mutual culture as the character of the nation. In realizing this, the system that ensures the implementation of structural education system that is structured and guarantee the right to get education for all the people of Indonesia. Organize a civic education system that creates solidarity and national solidity so that all the people of Indonesia feel the taste as a nation and make mutual cooperation as the practice of everyday life. This culture will create the character of a dignified nation and sustain the country's readiness in global life.

The research findings show that to establish cadre loyalty, the Nasdem Party of West Sumatera Province Leaders Council aligned political education materials that were planned, conceived and executed by referring to the party's vision, mission and platform of struggle. Political education activities are programmed and incidental. Nasdem Party through the field of political and cultural education provides political education materials such as (1) legislation including the laws of political parties, the law of regional head election and legislative elections; (2) practical knowledge of politics, political activity. one such practical knowledge is the knowledge of how to recruit society to be attracted to the party of nasdem and the problem of personality and behavior in practical politics; (3) political norms and ethics so that in politics do not violate ethics and norms that have lived and developed in society; (4) the cultivation of the concept of nationality, party ideology, the existence of party vision and mission, party programs and party jargon explored publicly; (6) cultural and territorial material within the province of western Sumatra; and (7) evidence of concrete activities of the party nasdem in society.

In addition, political education to female cadres was also provided by the women's wing organization GARNITA MALAHAYATI. The material given is more about improving the quality of human resources of female cadres in the field of economy and strengthening roles in households and communities while the material around practical politics such as providing increased human resources in women, direction in 
politics, and leadership. The material given for politics is more about women's leadership issues, both in the context of their role in the family, society and in political parties. Garnita encourages women through their potential to continue to improve quality and advance in practical politics. However, in the implementation of female cadre development activities, garnita is relatively less active when viewed from the intensity of activities held. The party emphasizes women empowerment in garnita malahayati as women's wing organization. However, as it is understood that the wing organization in the party's management structure is not included in the internal structure of party management but is a supporting system.

Based on the above explanation, it is illustrated that the materials given by political parties to the cadres have been referring to the vision and mission of the party by giving enlightenment to the cadres around the juridical foundation of political concept in Indonesia, ethics and political norms to build democratic society, empowerment in economy and leadership in strengthening roles in family and society. Party ideology is defined in the party platform. Nasdem's party struggle platform is further elaborated into 17 explanatory points covering the fields of science, politics, social, culture, economics, law, and defense-security. The ideology of the party is further described in the party platform which is a blueprint of the party's struggle line. In the political struggle platform of the nasdem party outlined in the 17 points of the various fields, in point 12, it states "Managing the growth of the population, realizing small and prosperous families, eradicating poverty, and optimizing the role of women and the young generation," with one strategic step of "optimizing resource mobilization by mobilizing youth potential and gender mainstreaming ".

However, the political platform has not been implemented optimally by the Nasdem party, because the seriousness in developing female cadres has not been shown by the program planning and budget specifically for the development of female cadres and political education materials that are appropriate to the needs of women cadres. In the platform of political parties has outlined a number of points of thought that the party brought as a derivative of the party ideology that contains the value of hope and ideals of the party [17]. However, not infrequently ideology is only used as a means of imaging alone to get the sympathy and voting from the voters. There is now a shift in the role of ideology, ideology that should be the basis of political parties and their cadres in doing political works involving many things but the ideology used as imaging content that is often manipulative. Ideology then only becomes accessories of political parties, ideology is defeated by the short-term interests of political party elites in the pursuit of personal interests. This can be seen from the number of elite political parties move from one party to another party [18].

The party of nasdem does not distinguish the form of political education activities of male and women cadres as well as unsustainable activities. Activities are carried out according to the needs of the political situation and conditions that occur and tend to lead to the strengthening of internal party organization. The same thing is also shown by other research on the guidance of female cadres in the four parties namely Gerindra Party, Golkar Party, PAN Party and Democrat Party, showed that generally the guiding material from the party structure is related to the nature of the party, and the party's mission and party's efforts in preparing its cadres to plunge into the world of practical politics [5]. The materials presented in cadre coaching are generally not devoted to women.

There needs to be a different emphasis on political education materials for women cadres because they have different needs and political knowledge base. That special treatment is necessary for women [5]. He also revealed that women occupy different positions in society, different experiences to fight for the specific needs and interests of women will be better represented by women. In addition, the party also plays the role of preparing female cadres as legislators because the purpose of political education for women cadres will surely refer to the representation of women in the parliament so that political education materials for women cadres should be relevant in accordance with the duties within the legislative body.

In addition, another reason for the differentiation of political education materials between men and women politicians is seen in terms of recruitment and political mobility. There are at least three profiles of women politicians based on their recruitment and social mobility process [10]. First, women who are involved in politics because they have independent intellectual and organizational abilities. This female politician model can be called achieved woman politician. Second, women who gain political office not because they fully have political skills or because of their business in a way, but they get a political position because of its relationship with certain men who have important political position. This kind of women politician is referred to as ascribed woman politician. Third, women politicians who reach political positions because they have collusion with bureaucracy. Politicians like this have patrons. Patrons are meant here are political elites who have great access to political power. Women party cadres have diverse reasons to join a political party but are more likely to be influenced by family relationships such as father, husband, older brother, cousin or collusion and nepotism relationships with the bureaucracy. However, it also does not neglect the intellectual and organizational skills of women cadres.

\section{CONCLUSION}

The material given by the party nasdem to the cadre has referred to the vision and mission of the party by giving enlightenment to the cadres around the legal foundations of political concept in Indonesia, ethics and political norms to build democratic society, empowerment in the field of economy and leadership in strengthening the roles in his family and community. The party of nasdem does not distinguish the form of political education activities of male and female cadres as well as unsustainable activities. Activities are carried out according to the needs of the political situation and conditions that occur and tend to lead to the strengthening of internal party organization. Political parties play a strategic role in shaping the political literacy of women cadres through the function of political education, so that not only the personality, awareness and participation of the cadre politics but also must be balanced with the loyalty of women cadres to the party. The loyalty of 
the cadres is determined by the knowledge and political awareness it possesses, one of which is obtained through the material of political education on a regular and ongoing basis. In the political education materials embedded in the ideology, platform, vision and mission of the party in order to prevent the birth of a jumping-finger politician or pragmatic-transactional flea politician and poor commitment to view politics only from power. The phenomenon of a jump-fence politician or a flea politician is not a good lesson for cadre's political education.

\section{ACKNOWLEDGMENT}

The author would like to thank the Endowment Fund for Education of the Republic of Indonesia (LDPD RI) which has funded the implementation of this research. Furthermore, the author also thanks to the entire academic members of Citizenship Education Department, School of Postgraduate Studies, Indonesia University of Education as an academic institution where the author gained knowledge in master's degree.

\section{REFERENCES}

[1] M. Budiardjo, Dasar-Dasar Ilmu Politik. Jakarta: Gramedia, 2013.

[2] J. Hamidi, and Mustafa L, Civic education: antara realitas politik dan implementasi hukumnya, Jakarta: Gramedia, 2010.

[3] S. Katz, Handbook Partai Politik, Bandung: Nusamedia, 2015.

[4] A. Muslimat, "Rendahnya Partisipasi Wanita Di Bidang Politik". Jurnal Studi Gender Dan Anak, vol.3, no. 2, Juli-Desember 2016.
[5] A. Rafni, and Aina, Pendidikan Politik. Padang: UNP Press, 2014.

[6] U. A. M. Ruslan, Pendidikan Politik Ikhwanul Muslimin, Solo: Era Intermedia, 2000 .

[7] I. Novianti, "Dilema Kepemimpinan Perempuan Dalam Islam", Yin Yang: Jurnal Studi Gender Dan Anak,vol.3, No.2. Juli-Desember 2008.

[8] S.M. Mulia and A. Farida, Perempuan Dan Politik, Jakarta: Gramedia, 2015.

[9] M. Zamroni, "Perempuan Dalam Kajian Komunikasi Politik dan Gender". Jurnal Dakwah, vol. XIV, no.1, 2013.

[10] A. Retnoningtias,"Keterlibatan Wanita Indonesia dalam Pengambilan Keputusan Politik Menurut Pandangan Gender", Skripsi-FISIP Universitas Jember, 1997.

[11] H. Patricia, "Political Gender Inequality And Infant Mortality In The United States, 1990-2012”. Social Science \& Medicine, 2017.

[12] S. Kumar and N Prakash, "Effect Of Political Decentralization And Female Leadership On Institutional Births And Child Mortality In Rural Bihar, India”, Social Science \& Medicine, 2017.

[13] R. York and S.E. Bell, "Life Satisfaction Across Nations: The Effects of Women's Political Status and Public Priorities", Social Science Research, 2014

[14] F. Fernando and J. Gyourko, "Does gender matter for political leadership? The case of U.S. mayors", Journal of Public Economics, no.112, pp. 24-39, 2014

[15] Sugiyono, Penelitian Kombinasi, Jakarta: Alfabeta, 2013

[16] T.M.P. Astuti, “Citra Perempuan Dalam Politik”, Yin Yang: Jurnal Studi Gender Dan Anak, vol.3, no.1, Januari-Juni 2008.

[17] L. Romli, "Masalah Kelembagaan Partai Politik di Indonesia Pasca Orde Baru", Jurnal penelitian politik, 2016

[18] I.Y. Prasetya, "Pergeseran Peran Ideologi Dalam Partai Politik", Jurnal Ilmu Politik Dan Ilmu Pemerintahan, vol. 1, no. 1, 2011. 